\title{
АКТУАЛЬНОСТЬ И ПУТИ РЕШЕНИЯ ПРОБЛЕМЫ ТРУДОУСТРОЙСТВА МОЛОДЕЖИ (НА ПРИМЕРЕ ЧЕЧЕНСКОЙ РЕСПУБЛИКИ)
}

Асхабова 3. P., Асхабов X.P. ГГНТУ имени акад. М. Д. Миллионщикова, г. Грозный, Россия

В данной работе рассмотрены проблемы трудоустройства молодежи. Выявлены основные барьеры, по причине которых молодой специалист не может трудоустрочться. Определена роль государства, в частности молодежной политики в повышении занятости населения. Проведен анализ данных о трудоустройстве населения органами службы занятости $и$ распределении численности занятых и безработных по возрастным группам. Доказано наличие проблемь трудоустройства молодежи в Чеченской Республике. Предложены пути решения исследуемой проблемы.

Ключевые слова: молодежь, трудоустройство, низкоквалифицированная работа, молодой специалист, молодежная политика.

Из-за сложившейся конъюнктуры рынка труда крайне актуальна проблема трудоустройства молодых специалистов в начале своей карьеры. Следует понимать, что она касается не только выпускника, но и работодателя.

В большинстве своем, не имея опыта работы и необходимых профессиональных навыков, молодые люди, впервые выходя на рынок труда, сталкиваются с серьезными трудностями при трудоустройстве и все это сопряжено несоответствием между их ожиданиями и потребностями с одной стороны, и тем, что работодатели требуют от них - с другой. Результаты успешной адаптации молодежи на рынке труда зависят от экономической ситуации в стране и от политики, которая проводится государством [5]. В свою очередь, отсутствие базовых компетенций, возможностей для обучения на протяжении всей жизни создает предпосылки социальное отчуждение порождает порочный круг занятости на рабочих местах низкого качества или безработицы, бедности и плохих условий жизни [6].

К вышесказанному также относится и то, что при найме на работу теоретические знания менее приоритетны, чем наличие практических навыков студента. Так, нехватка навыков и стажа, а в некоторых случаях и совмещение с учебой исключает возможность устроиться на высококвалифицированную и хорошо оплачиваемую работу [3].

В отличие от других возрастных групп соискателей молодые кадры испытывают проблемы с трудоустройством по причине их низкой конкурентоспособности, что также связано с недостатком профессиональных знаний, отсутствием необходимых трудовых навыков и умений. В данном 
случае сказывается нежелание работодателей нести издержки, связанные с организацией его дополнительного профессионального обучения [5].

Из-за столь высоких требований на рынке труда молодые кадры устраиваются на работу, не предъявляющая высоких требований, которые чаще всего оказываются в сфере низкоквалифицированного труда, где наем молодежи экономически выгоднее для работодателя.

Низкоквалифицированные должности должны быть временной мерой для решения проблем, связанных с финансами и нарабатыванием стажа. Так, сотрудники, занимающие низкоквалифицированные должности, сталкиваются со следующими проблемами:

- высокий уровень нагрузок, а иногда и переработки;

- низкая оплата труда;

- серьезные ограничения во времени.

По причине вышеописанных проблем наблюдается высокая текучка кадров на данных должностях, что исключает возможности проводить какиелибо дорогостоящие или же длительные курсы по обучению, подготовке сотрудников в сфере низкоквалифицированного.

Возвращаясь к теме молодых специалистов, только начинающих карьеру, следует отметить, что существуют барьеры, из-за которых работодатели испытывают настороженное отношение к молодежи, среди этих преград большее внимание уделяется таким требованиям, как профессиональный опыт и трудовые навыки, далее следуют завышенные ожидания к заработной плате, а также отсутствие определенной цели в построении карьеры вместе с психологической нестабильностью [3].

Наиболее сложным и одновременно важным требованием, предъявляемым со стороны работодателя к молодому специалисту является наличие опыта работы. Вся сложность заключается в том, что студенту очень трудно нарабатывать стаж вместе с учебой, из-за чего выпускник по окончании университета не может трудоустроиться по причине требований от работодателя [2].

Также вдобавок к вышеупомянутым проблемам ситуация осложняется еще и тем, что в современной России существуют два независимых рынка: рынок образования и рынок труда. Большинство учебных заведений направлены на абитуриентов и их родителей, а последние, выбирая специальность и место дальнейшего обучения, не ориентируются на ситуацию на рынке труда [5]. Эти проблемы усугубляются в условиях нестабильности, когда одни профессии становятся невостребованными, а другие, напротив, оказываются на пике спроса, в то время как система образования не может оперативно отреагировать на изменяющиеся запросы со стороны рынка труда [6]. Вследствие чего в Российской Федерации существует переизбыток кадров таких специальностей, как экономист, юрист, психолог.

В решении проблемы трудоустройства молодых кадров важную роль играет государство, в частности ее молодежная политика. Таким образом, удовлетворение потребности рынка труда в молодых специалистах 
осуществляется через спрос на образовательный сектор в форме государственного заказа со стороны экономики, а в форме различных договоров с самими вузами - со стороны работодателей.

Не менее важным является и то, что следует определиться с тем, какие специалисты и в каком количестве нужны для развития экономики на данный период ее развития и в будущем, для того, чтобы не допускать проблем, связанных с неравномерностью между спросом и предложением на рынке труда $[5]$.

Изучаемая проблема представляется крайне актуальной как по стране в целом, так и по регионам в отдельности. В нашем случае, исследование проводилось на примере Чеченской Республики.

Задачи социально-экономического развития региона и стратегические ориентиры государственной политики в социально-экономической сфере представляют собой приоритеты развития молодежной политики Чеченской Республики [4].

Для обозначения наличия проблемы с трудоустройством молодежи в Чеченской Республике обратимся к анализу данных о трудоустройстве населения органами службы занятости из таблицы 1 и распределении численности занятых и безработных по возрастным группам из таблицы 2.

Таблица 1 - Трудоустройство населения органами службы занятости

\begin{tabular}{|c|c|c|c|c|}
\hline & Всего & $\begin{array}{c}\text { Занятые трудовой } \\
\text { деятельностью }\end{array}$ & $\begin{array}{c}\text { Незанятые } \\
\text { трудовой } \\
\text { деятельностью } \\
\end{array}$ & $\begin{array}{c}\text { Ищущие } \\
\text { первую } \\
\text { работу } \\
\end{array}$ \\
\hline \multicolumn{5}{|c|}{ Обратились по вопросу трудоустройства } \\
\hline 2005 & 235054 & 5556 & 229498 & 96549 \\
\hline 2010 & 195984 & 11406 & 184578 & 111671 \\
\hline 2015 & 86378 & 3941 & 82437 & 50608 \\
\hline 2017 & 61353 & 1011 & 60342 & 25896 \\
\hline 2018 & 60148 & 2089 & 58059 & 24036 \\
\hline \multicolumn{5}{|c|}{ Трудоустроены } \\
\hline 2005 & 47124 & 5556 & 41568 & 23267 \\
\hline 2010 & 66626 & 11399 & 55227 & 38932 \\
\hline 2015 & $\mathbf{1 7 0 3 5}$ & 3877 & 13158 & 12127 \\
\hline 2017 & 13480 & 983 & 12497 & 8941 \\
\hline 2018 & 20586 & 2067 & 18519 & 12386 \\
\hline
\end{tabular}

Примечание - Источник: [1, С. 36, таблица 5.16]

Из анализа таблицы 1 видно, что имеется неоднозначная тенденция в трудоустройстве населения региона. Так, с 2005 до 2010 года общая численность трудоустроенных имела тенденцию к росту, однако с 2010 по 2017 год значение данного показателя уменьшилось. Следует отметить, что в 2018 году было трудоустроено всего 20586 человек, что на 64,6\% больше, чем в 2017 году. С другой стороны, количество обратившихся в органы службы занятости имеет прочную тенденцию к снижению. Так, в 2018 году численность обратившихся была равна 60148, что на 30,4\% меньше, чем значение 
показателя за 2015 год, это связано с уменьшением численности обратившихся из групп незанятых трудовой деятельностью и ищущих первую работу. Так, в 2018 году из 24036 человек, ищущих первую работу и обратившихся по вопросу трудоустройства в органы службы занятости были трудоустроены только половина из них, то есть 12386 человек.

Исходя из вышеописанного в Чеченской Республике также существует проблема трудоустройства молодых специалистов. Однако, для полной картины ситуации обратимся к данным о распределении численности занятых и безработных по возрастным группам в таблице 2.

Таблица 2. - Распределение численности занятых и безработных по возрастным группам в 2018 году (в процентах к итогу)

\begin{tabular}{|l|l|l|l|l|l|l|}
\hline & \multicolumn{5}{l|}{ Занятые } & \multicolumn{2}{l|}{ Безработные } \\
\cline { 2 - 7 } & Всего & Мужчины & Женщины & Всего & Мужчины & Женщины \\
\hline Всего & $\mathbf{1 0 0}$ & $\mathbf{1 0 0}$ & $\mathbf{1 0 0}$ & $\mathbf{1 0 0}$ & $\mathbf{1 0 0}$ & $\mathbf{1 0 0}$ \\
\hline В том числе в возрасте, лет \\
\hline $15-29$ & 32,4 & 29,1 & 36,4 & 64,7 & 72,5 & 60,1 \\
\hline $30-39$ & 32,1 & 33,5 & 30,4 & 17,9 & 10,8 & 22,2 \\
\hline $40-49$ & 19,4 & 20,2 & 18,4 & 13,5 & 15,1 & 12,5 \\
\hline $50-59$ & 14,0 & 14,9 & 13,0 & 2,1 & 0,9 & 2,8 \\
\hline
\end{tabular}

Примечание - Источник: [1, С. 34, таблица 5.9 и таблица 5.11]

По данным таблицы 2 видно, что в 2018 году среди безработных большую их часть составляет молодежь от 15 до 29 лет или 64,7\% от всей численности безработных. Среди мужской части в возрасте от 15 до 29 лет безработных больше, чем среди женской части того же возраста. Занятая молодежь в возрасте от 15 до 29 лет в 2018 году превосходит по численности остальные возрастные группы. По половому разделению, женщин занятых в возрасте от 15 до 29 лет больше, чем занятых мужчин тех же возрастных групп.

Из вышесказанного следует, что молодежь в возрасте от 15 до 29 лет среди занятых является ключевой возрастной группой, которая превосходит по численности остальные. Но вместе с тем, именно в данной возрастной группе находится наибольшая доля безработных.

Таким образом, из всего анализа следует, что молодые кадры сталкиваются с проблемой трудоустройства и в Чеченской Республике, однако сложившаяся ситуация не является неразрешимой.

Разрешить проблемы трудоустройства молодежи следует посредством разработки и реализации программ молодежной политики, которые содержат инструментарий, направленный на улучшение мер социальной защиты молодежи, раскрытие ее человеческого потенциала [7]. Одной из таких программ является государственная программа «Развитие молодежной политики Чеченской Республики» на период до 2022 года, в цели которой входит:

- развитие сферы молодежной политики Чеченской Республики путем создания благоприятных для этого условий; 
- провести мероприятия для вовлечение молодых людей в предпринимательскую деятельность и создать условия, которые бы стимулировали активность молодежи в сфере предпринимательства;

- повысить социальную и экономическую активность молодежи Чеченской Республики путем создания для этого соответствующих условий.

Для выполнения вышеописанных целей имеется следующий комплекс эффективных мероприятий:

- поддержать инновационное творчество детей и молодежи, в том числе в целях профессиональной реализации и обеспечить самозанятость молодежи;

- повысить экономическую активность молодежи путем создания стимулирующих условий, которые включают в себя обучение основам бизнеспланирования, содействие занятости местности и вовлечение в реализацию программ экономического развития;

- проведение ярмарок вакансий, профессионального обучения и переподготовки безработных граждан профессиям и специальностям, актуальным на рынке труда и содействие в трудоустройстве;

- принятие необходимых мер по трудоустройству учащейся молодежи в период летних каникул.

В условиях экономической нестабильности вопросы трудоустройства молодежи становятся все более актуальными. Осознавая складывающуюся ситуацию, молодые люди начинают искать новые способы реализации своего потенциала, в том числе в сфере предпринимательства. Малый и средний бизнес призван сформировать средний класс - надежную опору инновационных преобразований в экономике и социальной сфере. Для этого первоначально требуется обучение элементарным навыкам бизнеспланирования с целью решения вопросов самозанятости и развития малого и среднего предпринимательства.

Некоторые исследователи данной проблемы считают, что для начального и минимального решения проблемы трудоустройства молодого специалиста необходима помощь государства и органов местного самоуправления в каждом регионе. Если решать проблему на уровне отдельного региона, то общая картина снижения безработицы страны будет оптимистичной. Эффективным путем решение данной проблемы станет взаимодействие и сотрудничество всех структур: государственных органов власти, службы занятости населения, сферы образования и комитетов по делам молодежи. На первый взгляд, задача абсолютно не сложная для нашего времени. Возможно создание реестра, который позволит регулировать отношения на рынке труда, что станет одним из способов контроля за перенасыщением рынка специалистами либо за его скудностью [2].

Другие ученые высказывают следующую позицию: для повышения занятости молодежи необходимо использовать налоговые льготы, предоставляемые работодателю для трудоустройства на работу молодых специалистов, их дальнейшему профессиональному обучению, повышению квалификации и переподготовки. Также следует вовлекать молодежь как можно 
раньше в процесс приобретения трудовых навыков и в трудовую деятельность. Таким образом, изменяющиеся условия различных сфер общественной жизни требуют от государства нового подхода к обучению молодежи, помощи в организации ее взаимодействия с работодателями. Главный смысл данного подхода - обучение специалистов, способных выдерживать конкуренцию на рынке труда, решать актуальные социально-экономические задачи, участвовать в процессе развития страны [5].

Также относительно проблемы трудоустройства молодежи есть третье справедливое мнение, которое указывает на комплекс мер для решения данного вопроса:

- во время учебного процесса студенту следует получить некоторое количество часов практики, совмещенной с учебным процессом.

- каждое учебное заведение должно содействовать выпускнику с трудоустройством;

- следует сделать строгий отбор абитуриентов на гуманитарные специальности вместе с поощрением технических направлений [2].

Таким образом, молодежь - это социально-демографическая группа, выделенная определенными возрастными рамками, характерной чертой которой являются ограничения, связанные с доступом к экономическим, социальным и культурным ресурсам. Одной из причин возникновения вышеперечисленных ограничений является проблема трудоустройства молодежи, для разрешения которой следует еще со школьной скамьи проводить профориентационные мероприятия для школьников, направленные на ознакомление с перспективными профессиями. А студентам в учебных заведениях следует получать некоторое количество часов практики, совмещенной с учебой, при последующем содействии учебного заведения в трудоустройстве выпускника.

\section{Исследование выполнено при финансовой поддержке РФФИ в рамках научного проекта №18-010-00182.}

\section{Список литературы}

1. Чеченская Республика в цифрах. 2019: Краткий статистический сборник / Чеченстат - Грозный 2019. - 168 с.

2. Андреева Н.С. Проблема трудоустройства молодежи // Вестник молодежной науки. 2017. №3 (10). C. 1-7 URL: https://cyberleninka.ru/article/n/problema-trudoustroystva-molodezhi-1 (дата обращения: 18.11.2019).

3. Журавлева И.И., Тимошкова Н.Д. Исследование проблем трудоустройства молодежи // Бизнес-образование в экономике знаний. 2017. №1 (6). C. 44-48. URL: https://cyberleninka.ru/article/n/issledovanie-problemtrudoustroystva-molodezhi (дата обращения: 18.11.2019). 
4. Саралинова Д.С. Приоритеты развития молодежной политики Чеченской Республики // Молодой ученый. — 2016. — №11. - С. 953-954. URL https://moluch.ru/archive/115/30857/ (дата обращения: 18.11.2019).

5. Скударева Н.3. Проблема трудоустройства молодежи на рынке труда // Вестник МФЮА. 2017. №1. С. 294-301 URL: https://cyberleninka.ru/article/n/problema-trudoustroystva-molodezhi-na-rynke-truda (дата обращения: 18.11.2019).

6. Устинова К.А., Попов А.В. Объективные и субъективные барьеры трудоустройства молодежи в современной России // Вестник НГУЭУ. 2018. №3. C. 51-64. URL: https://cyberleninka.ru/article/n/obektivnye-i-subektivnyebariery-trudoustroystva-molodezhi-v-sovremennoy-rossii (дата обращения: 18.11.2019).

7. Шаповалова И.С., Маликова Е.В. Реализация государственной молодежной политики в России: региональный аспект // Теория и практика общественного развития. $2018 . \quad$ №6. URL: https://cyberleninka.ru/article/n/realizatsiya-gosudarstvennoy-molodezhnoy-politikiv-rossii-regionalnyy-aspekt (дата обращения: 18.11.2019). 